\title{
REPRESENTATION OF WISDOM IN THE BOOK OF PROVERBS WRITTEN BY SOLOMON
}

\author{
Marudut Bernadtua Simanjuntak \\ Vocational School, IPB University \\ bernadmarudut@gmail.com
}

\begin{abstract}
This article aims to describe the book of Proverbs for how someone gets wisdom, which the ability to understand everything clearly and use knowledge to overcome a problem. The problem in this study is how verses in the Book of Proverbs can represent wisdom that aims to teach someone to understand each teaching. This research is a qualitative research using descriptive method. The data are taken from The Book of Proverbs written by Solomon. Data collection techniques are reading analysis and documentation. This study uses three steps of work, they are (1) providing data; (2) data analyzing; and (3) presenting the results of the data analysis. This study uses pragmatic theory. The results of this study indicate that verse fragments in articles taken from the Book of Proverbs can teach someone to have wisdom, that wisdom can direct people into discipline, happiness and achievement of success.
\end{abstract}

Keywords: Representation, Wisdom, Proverbs, Solomon

\section{INTRODUCTION}

\section{Literature Background}

Literary works can describe social life because the existence of literature comes from views, problems or life in accordance with the perspective of literary writers. Literary works can influence one's thinking because it can trigger understanding, questions, and debate. Even in many aspects, literary works can influence understanding, teachings, and rules. Literary books such as the Bible and Mein Kamp have shown evidence in the world about how a group of people and even the world can be influenced by writers through their literary work. Literary flexibility is a power that is able to enter various aspects of life. Of the many problems of life, one is able to create reflections that are enshrined in the form of literary works.

One of the literary works that have been widely read by various groups in the world is the Book of Proverbs. The book of Proverbs is a literary work written by Solomon even before the majority of the teachings of religion in the world emerged. This book has been translated into many languages in the world because basically, the Book of Proverbs is a part of the scriptures that are believed, trusted, and inspired as a true basis in religion. The writings in the Book of Proverbs focus a lot on wisdom 
or wisdom which aims to know education, understand meaningful words, receive education that can educate readers and teach the truth. The purpose of this study is to describe the representation of wisdom contained in the Book of Proverbs. As one of the books in the scriptures, Proverbs is a simple reading because it is in the form of poetry that is light and can be read and understood simply.

\section{2.. Literary work}

Literary work is a representation of cultural life created in the form of the imagination and creativity of the writer. Events in literary works, in this case, objects that are one of the books are factual events or events that teach experiences in life. Books as written works which are part of literary forms contain the contents of reality where there are events or events and behaviors that are experienced and made by humans. Learning can be taken from the literature so that benefits can be taken as life guidelines to make it better. Literature is often understood as an attempt to represent real events. Often, literary works are understood as imitations and imitations of actual events at the time of writing.

According to Wibowo (2013: 65), literary works can represent cultural and cultural values and groups of people as a form of material expression from human experience. This is also supported by Saptawuryandari (2015: 195) who argues that literary works can show the shadow of a real and educated social life. From these statements, literary works cover the lives of individuals, communities, the environment, and events that occur. Literary works in the view of Hurdjana (Nurhajarini \& Suyami, 1999: 45) have important ideas or messages expressed by the author because the work is not suddenly made without purpose.

In its influence and function, literary works have several roles. According to Teeuw (2003: 19), literary works act as evaluators of the social maturity of readers who are considered capable of formulating human morality and character. On the other hand, Damono (1984: 1) argues that literary works are indicators made by writers that aim to be understood, appreciated and used by various elements of society, especially students as readers. Another role, according to Kanzunnudin (Qur 'ani, 2018), literature can be a medium that has a reciprocal relationship with one human being with another in a social environment. It is hoped that the literary product of the writer can be part of the community and can be used to improve the quality of life.

\section{Proverbs book}

The book of Proverbs is estimated to be made in the period around $900 \mathrm{BC}$. In his time, people around Solomon reached the top in various ways such as government, spirituality, politics, and culture. This book is a literary work specifically made to educate the public in obtaining wisdom. This book is a wisdom of literacy arranged in the form of poetry and poetry containing advice. According to Lasor (2005: 67), the Book of Proverbs is a collection of writings of various different styles so that it 
shows a broad scope so that it can be compared. The book of Proverbs has five writing patterns which can be explained as follows:

a. Part One: "Wisdom to guide the heart". This section is a message poem consisting of short conversations between families. This discusses the consequences of lack of wisdom. This section includes the Proverbs Book from the first chapter to eighteen.

b. Part Two: "Wisdom in choosing". In this second part, book readers are expected to be able to apply wisdom in complicated situations in life. This section includes Proverbs Books from chapters ten to twenty-four.

c. Part Three: "Wisdom is built". In the third part of this book, advice and guidance are given which includes things such as honor, how to deal with fools, heartache caused by friends, attention to the responsibilities and consequences of an evil government. This section includes the Book of Proverbs from chapters twenty to twenty-nine.

d. Part Four: "First Important News". In this section, the important news in question is how to deal with cases based on human incompetence. This section includes the thirtieth Book of Proverbs.

e. Part Five: "Second Important News". In this last section, it is written in two types of writing styles. The first part talks about a collapse that can be experienced by a woman who is not recommended and should be avoided, and in the second part specifically concerning the classic description of an ideal woman. This section includes the thirtieth chapter of the Book of Proverbs.

\section{The Book of Proverbs}

Proverbs was written by Solomon. This can be seen from the writing of the first chapter and verse about the Book of Proverbs which clearly writes Proverbs Solomon, son of David, King of Israel. Although there are names like Agur and Lemuel, these names are believed to be other nicknames for Solomon. In the view of religion such as Christianity and Muslims, Solomon was known as the King, Prophet, Teacher and wise man.

\section{Representation of Wisdom}

According to Sulistiyana (2014: 43), representation is a picture of an object that represents a situation. This opinion is supported by Hall (1995: 69) who considers that representation makes concepts in the mind by using language to interpret abstract or concrete objects. By understanding representation, all objects can be correlated with concepts that are in the reader's knowledge.

\section{METHODS}

In the research of this book, the method used is a qualitative descriptive method. Sukardi $(2009,157)$ argues that this method is a research method that describes or represents objects in abstract or concrete forms. Data collection techniques are carried out in the form of observations and documentation that 
support how to analyze the representation of wisdom. This is in line with the opinion of Mahsun (2005: 90) who argues that qualitative data collection must be done by the technique of recording, observing and recording. The object of this qualitative research is the Book of Proverbs written by Solomon. But to simplify and limit the research in this book, the author uses ten models of wisdom representation to be presented in three stages that follow the stages of Sudaryanto's theory (1993: 34), namely (1) data collection, (2) data analysis, (3) presentation of results data analysis.

\section{FINDINGS AND DISCUSSIONS}

Based on the introduction described above and the purpose of this study, Proverbs has been analyzed to understand the representations of wisdom. The wisdom representations of wisdom in the Book of Proverbs are described as follows.

\section{a. The Voice of Woman in the Open Squares}

\section{1:20 Wisdom calls aloud outside;}

She raises her voice in the open squares.

(World English Proverbs- written by Salomon 1:20)

Analysis: In the author's understanding, the paraphrase means wisdom calls and shouts loudly and loud in the open. Another interesting thing in these sentences means that wisdom is indicated as the woman who cries out. As discussed earlier, wisdom alone is an abstract noun. But in the representation of wisdom, the understanding that can be understood is that wisdom acts as a woman who calls on people she wants to be willing to teach in the open. Even in the next explanation, the female character which also indicates the figure of the mother who wants to teach and educate is a fairly representative representation of wisdom. Then another analysis is, why should people listen to the wisdom that is loud and clear according to the understanding of the paraphrase? As explained in the next chapter that to obtain the benefits of getting wisdom, one must have intimacy with the creator by listening carefully. In the third chapter, it is explained again about this understanding that wisdom is a very basic thing. With the ability to think after listening to the call like the call of a mother who loves her children, that is wisdom that always teaches someone to listen so that understanding of wisdom becomes very clear.

\section{b. The Fear of the LORD}

1:7 The fear of the LORD [is] the beginning of knowledge,

[But] fools despise wisdom and instruction.

\section{(World English Proverbs- written by} Salomon 1:7)

Analysis: Wisdom is represented as a form of "The fear of the LORD". The fundamental difference between fear, frightened and scared is based on the introduction of one person to another. In this paraphrase, "The fear of LORD" means a feeling of fear because of the recognition of obeying, respecting and carrying out a command. Why is fear of LORD becoming the beginning of knowledge? This is because, without fear, humility and respect will not appear to accept a 
teaching or knowledge. Higher and honorable than all leaders in the world, having God is the initial leader in the universality of self and the human soul. "The fear of LORD" became the beginning of a beginning in achieving the foundation of wisdom. In the next sentence, it explains that "the fools" who despise wisdom and instruction indicate fear and disrespect for people to LORD.

c. Lips of an Immoral Woman, Harlot, and Seductress

5:3 For the lips of an immoral woman drip honey,

And her mouth [is] smoother than oil;

5:4 But in the end she is bitter as wormwood, Sharp as a two-edged sword.

23:27 For a harlot [is] a deep pit, And a seductress [is] a narrow well.

23:28 She also lies in wait as [for] a victim, And increases the unfaithful among me (World English Proverbs- written by Salomon 5:3-4, 23:27-28)

Analysis: In the discussion in the previous article, wisdom is represented as the woman who calls. Only, in this third representation, the representation of wisdom is "Lips of a moral woman". To explain more about "Lips of a moral woman", the author uses an antonym explanation not to be carried out so that the representation of wisdom is not listening or making an explanation of the meaning of "Lips of an immoral woman" and "harlot". How is a prostitute indicated like bitter as wormwood, sharp as a two-edged sword, a deep pit, and narrow well? Animals are entangled in long or entanglement made by hunters. It means a person who has no wisdom is indicated as a subscription from a prostitute entangled in immorality. Even the understanding of "deep pit and narrow well" indicates the difficulty of someone who is not wise will be troubled in the end. In the book of Proverbs in the seventh chapter explained more deeply for those who deal with such people can experience emotional and physical harm.

\section{d. A Master Craftsman}
8:30 Then I was beside Him [as] a master craftsman; And I was daily [His] delight, Rejoicing always before Him,

(World English Proverbs- written by Salomon 8:30)

Analysis: Wisdom representation in the fourth part is personified as "a master craftsman". This personification is not only a means of literature in explaining wisdom characteristics but figuratively someone who has wisdom. In this paraphrase, it is explained that wisdom becomes "A master craftsman" because of the daily life of the LORD. The wisdom in his explanation is obtained from daily life together with LORD and always rejoicing the giver of wisdom himself. In the Twenty-second book of Proverbs in chapter 8 verse, it is explained that wisdom is exemplified as someone who becomes an expert worker who actively works with his father in dealing with all matters. 


\section{e. A Ring of Gold in a Swine's Snout}

11:22 [As] a ring of gold in a swine's snout, [So is] a lovely woman who lacks discretion.

(World English Proverbs- written by Salomon 11:22)

Analysis: In the above sentences, the explanation of wisdom representation is explained in the antonym explanation of the absence of wisdom, such as "a ring of gold in a swine's snout". How can the wisdom represent as a woman be a gold earring on a pig's nose? Gold earrings inserted on the side of the nose or a septum that separates the nostrils states a custom of eastern society that the woman is someone who is highly cultured and honorable. This can also be translated as wisdom which is considered valuable as gold. But in the subsequent explanation, most of the customs and traditions in Solomon's government considered pigs to be animals of low caste, unclean and disgusting. The author understands that a woman who is beautiful but has no sense is like a gold earring which is considered valuable is not suitable to be installed on a pig's nose.

\section{f. "Exalting His Gate" and "Having a Perverse Tongue"}

17:19 He who loves transgression loves strife, And he who exalts his gate seeks destruction.

17:20 He who has a deceitful heart finds no good, And he who has a perverse tongue falls into evil.

(World English Proverbs- written by Salomon 17:19-20)
Analysis: In this paraphrase, the author also uses the antonym of wisdom itself. In this representation, lack of wisdom is indicated such as "Exalting his gate" and "having a perverse tongue". Wisdom in this understanding translates into a person's speech in using the mouth. Is there something wrong with "Exalts his gate"? The author understands that someone who is not wise is like someone who loves transgression and strife exalts his gate. In eastern adat, the door should be closed tightly so that dust and animals do not damage the whole house. In fact, someone who does not make low doors to his home and yard will be at risk of being entered by thieves. This proverb intends to explain someone who is not wise making his mouth an elevated door through boasting and arrogant words. These words will foster contention and lead to a problem and disaster. The understanding also has the same meaning as the "perverse tongue" which indicates that someone who has a cunning heart which is opposition to wisdom, will not be able to find anything good. Eventually, these people will fall into evil.

\section{g. Having a Pity on the Poor}

19:17 He who has pity on the poor lends to the LORD,

And He will pay back what he has given.

(World English Proverbs- written by Salomon 19:17)

Analysis: By having pity on the poor, this can be an attitude where LORD will be flexible. This understanding in paraphrase is to obtain wisdom, it takes LORD's generosity in giving 
one's own wisdom to someone. Wisdom representation, in this case, is an attitude of helping weak people. In happy words, weak and poor people belong to LORD. In the fourteenth chapter and in Luke's book, it is explained that if love and mercy encourage someone to show kindness to the poor or give gifts to them, without expecting their reward, LORD considers giving such a loan to Him who will be paid back with wisdom, blessings, and blessings.

\section{h. The Sharpened Countenance}

\section{7:17 [As] iron sharpens iron, So a man sharpens the countenance of his friend.}

(World English Proverbs- written by Salomon 27:17)

Analysis: The next representation of wisdom is "The sharpened countenance". Iron can be used to sharpen blades made of the same metal. Similarly, someone can succeed in sharpening the intelligence and understanding of others. Wisdom gained from teaching tends to be better used when used in social life. Reminding one another and teaching one another is the attitude of gaining wisdom. If disappointment and a relationship with a mismatched person make other people sad, the sympathetic face of his friend can be truly uplifting. Our sad faces will change for the better, and we are encouraged by new hopes for new actions. This makes wisdom better in a person, both in intelligence and emotional.

\section{i. Scoffers and Wise Men}

29:8 Scoffers set a city aflame, But wise [men] turn away wrath.

29:9 [If] a wise man contends with a foolish man,

Whether [the fool] rages or laughs, [there is] no peace.

(World English Proverbs- written by Salomon 29:8-9)

Analysis: The representation of wisdom in this section uses comparisons. How can bullies "light up a country"? Braggers who do not respect authority and teachings speak disrespectfully to those around them. This causes them to inflame the fire of conflict, ignite the problem and make a big flame so that the city residents get burned. But the wise man extinguishes anger, speaks meekly and uses reason. This can extinguish the flame of anger and develop peace. In the absence of wisdom in the fool, he will go berserk and laugh because there is nothing inside him.

\section{j. Strong Drink and Wine}

31:6 Give strong drink to him who is perishing, And wine to those who are bitter of heart.

31:7 Let him drink and forget his poverty, And remember his misery no more.

(World English Proverbs- written by Salomon 31:6 -7)

Analysis: The representation of wisdom in paraphrase is a strong drink and wine. It is understood that many cultures that alcoholic beverages such as strong drinks and wine are not good for people's health. Then why give 
wine to those who are hard-hearted, wine wines to those who are bitter of heart? Alcoholic drinks and intoxicating wines are tranquilizers. The author understands that the usefulness of wisdom is to motivate someone who is in many problems, heartache, soul bitterness and even the one who leads to death. The above paraphrase does not indicate the existence of wisdom as a strong drink and wine, but as an entertainer and tranquilizer in distress.

\section{CONCLUSION}

Based on data analysis, it can be concluded that various forms of objects, abstract, concrete and paraphrasing can represent wisdom which is the ability to understand everything clearly and use knowledge to overcome a problem. In various analyzes, it can be concluded that the use of representation can make the reader of the Book of Proverbs obtain wisdom that is useful for: being a good listener and wise students, fearing the LORD, away from the words of an immoral woman, prostitute, and tempter to become good craftsmen in everyday life, to be wise in every condition and culture, be humble, pity the poor, encourage and motivate each other, quell anger, speak softly and use excuses, and entertain people in trouble.

\section{REFERENCES}

Barker, C. (2009). Cultural Studies: Teori dan Praktik. Bantul: Kreasi Wacana.
Bible. (2003). The Books of Proverbs - The New King James Version. Jakarta: LAI

Damono,S.J. (1984). Sosiologi Sastra. Jakarta: Depdikbud

Hall, S. (1995). Representation: Cultural Representation and Signifying Practices. London: Sage Publications.

Lembaga Alkitab Indonesia. (2000). World English Proverbs. Jakarta: LAI.

Mahsun. (2005). Metode Penelitian Bahasa. Jakarta: PT. Rajagrafindo persada.

Nurhajarini, D.R. \& Suyami. (1999). Kajian Mitos dan Nilai Budaya dalam Tantu Panggelaran. Jakarta: Depdikbud

Qur"ani, H.B. (2018). Nilai-Nilai Pendidikan Karakter Babad Tanah Jawa. Jentera Jurnal Kajian Sastra.

Saptawuryandari, N. (2015). Pandangan Dunia Mochtar Lubis dalam Novel Senja. Jakarta: Aksara

Sudaryanto. (1993). Metode dan Aneka Tehnik Penelitian Bahasa. Yogyakarta: Duta Wacana University Press.

Sukardi. (2009). Metodologi Penelitian Pendidikan (Kompetensi dan Praktiknya). Jakarta: Bumi Aksara.

Sulistiyana, P. (2014). Representasi Kemiskinan dalam Novel Jatisaba Karya Ramayda Akmal (Kajian Sosiologi Sastra). Bahtera Sastra: Antologi Bahasa dan Sastra Indonesia, 2.

Teeuw, A. (2003). Sastra dan Ilmu Sastra. Jakarta: Pustaka Jaya

Wibowo, A. (2013). Pendidikan Karakter Berbasis Sastra (Internalisasi NilaiNilai Karakter Melalui Pengajaran Sastra).Yogyakarta: Pustaka Pelajar. 